\title{
DEEP CIRCULATION AND MERIDIONAL OVERTURNING: RECENT PROGRESS AND A STRATEGY FOR SUSTAINED OBSERVATIONS
}

\author{
S. R. Rintoul ${ }^{(1)}$, M. Balmeseda ${ }^{(2)}$, S. Cunningham ${ }^{(3)}$, B. D. Dushaw ${ }^{(4)}$, S. Garzoli ${ }^{(5)}$, A. L. Gordon ${ }^{(6)}$, P. Heimbach $^{(7)}$, \\ M. Hood ${ }^{(8)}$, G. C. Johnson ${ }^{(9)}$, M. Latif ${ }^{(10)}$, U. Send ${ }^{(11)}$, C. Shum ${ }^{(12)}$, S. Speich ${ }^{(13)}$, D. Stammer ${ }^{(14)}$ \\ (1) CAWCR, CSIRO and ACE CRC, GPO Box 1538, Hobart, Tasmania 7001 Australia, \\ Email: steve.rintoul@csiro.au \\ (2) ECMWF, Shinfield Park, Reading RG2 9AX, UK, Email: Magdalena.balmeseda@ecmwf.int \\ ${ }^{(3)}$ National Oceanography Centre Southampton, European Way, Southampton, SO14 3ZH, UK, \\ Email:scu@noc.soton.ac.uk \\ ${ }^{(4)}$ Applied Physics Laboratory, University of Washington, 1013 NE 40 ${ }^{\text {th }}$ St., Seattle, WA 98105-6698, USA, \\ Email: dushaw@apl.washington.edu \\ ${ }^{(5)}$ NOAA/AOML 4301 Rickenbacker Causeway, Miami FL 33149, Email: Silvia.Garzoli@noaa.gov \\ (6) Lamont-Doherty Earth Observatory, 61 Route 9W, Palisades, NY 10964, USA, \\ Email: agordon@ldeo.columbia.edu \\ (7) MIT, EAPS 54-1518, 77 Massachusetts Ave, Cambridge MA 02139 USA, Email: heimbach@mit.edu \\ ${ }^{(8)}$ Intergovernmental Oceanographic Commission of UNESCO, France, Email: maria.hood@ioccp.org \\ ${ }^{(9)}$ NOAA/PMEL, 7600 Sand Point Way NE, Seattle, WA 98115 USA Email: gregory.c.johnson@noaa.gov \\ (10) Leibniz-Institut für Meereswissenschaften, Düsternbrooker Weg 2024105 Kiel, Germany, \\ Email: mlatif@ifm-geomar.de \\ ${ }^{(11)}$ Scripps Institution of Oceanography, Mail Code 0230, UCSD, La Jolla, CA 92093-0230, USA, \\ Email: usend@ucsd.edu \\ ${ }^{(12)}$ Division of Geodetic Science, School of Earth Sciences, Ohio State University, 125 S Oval Mall, 221B Mendenhall \\ Lab, Columbus, Ohio 43210-1398, USA, Email: ckshum@osu.edu \\ ${ }^{(13)}$ LPO, UMR6523 CNRS/IFREMER/UBO, 6, av Le Gorgeu C.S. 93837, 29238 Brest Cedex 3 FRANCE, \\ Email: Sabrina.Speich@univ-brest.fr \\ ${ }^{(14)}$ Center for Marine and Climate Research, KlimaCampus Universität Hamburg, Bundesstr. 53 \\ 20146 Hamburg, Germany, Email: detlef.stammer@zmaw.de
}

\begin{abstract}
The global overturning circulation (OC) and its deep branch strongly influence phenomena of direct interest to society, including climate change and variability, sea level, temperature and rainfall patterns over land, global biogeochemical cycles and marine productivity. Observations of the deep ocean remain scarce, limiting our ability to understand and predict the overturning and deep circulations, their response to changes in forcing, and the impact of changes in the deep ocean on marine ecosystems, biogeochemical cycles and global climate. However, substantial progress has been made in recent years, including quantitative estimates of the strength of the global overturning circulation; the first time series measurements of the Atlantic meridional overturning circulation; evidence for changes in temperature, salinity and carbon in the deep ocean; and a deeper understanding of the role of the deep ocean and $\mathrm{OC}$ in low-frequency climate variability. These advances provide a guide to the design and implementation of a sustained observing system for the deep ocean and OC. We outline a strategy for sustained observations of the deep ocean that begins with tools available now, primarily repeat hydrography and
\end{abstract}

moored arrays spanning deep boundary currents, key passages, and ocean basins where feasible. New technologies - including profiling floats and gliders capable of sampling the full ocean depth, long-duration moorings with data telemetry, and new sensors are needed to complete a comprehensive observing system for the deep ocean.

\section{INTRODUCTION}

Roughly half the world ocean volume lies below 2000 $m$ depth. While Argo (Array for Real-time Geostrophic Oceanography) floats and satellite remote sensing have revolutionised our ability to measure the upper layers of the ocean, the deep ocean is beyond the reach of these tools and remains very poorly sampled. Growing recognition of the intimate link between the deep ocean and the evolution of climate has underscored the need for sustained observations of the "deep half" of the ocean.

The global ocean circulation is frequently conceptualized in terms of its zonally-integrated transport, referred to as the meridional overturning circulation or MOC. Here we focus on the global-scale, 
three-dimensional overturning circulation, for which the term MOC is not entirely appropriate, with its emphasis on a zonal-integral view and neglect of zonal flows that make an important contribution to the global-scale overturning and associated property fluxes. Here we use the more general term overturning circulation (OC).

The OC is a primary mechanism for the transport and storage of heat, freshwater and carbon by the ocean and therefore has a large impact on climate variability and change. The OC links each of the basins and spans the full-depth of the global oceans. Both wind- and buoyancy-forced circulations contribute to the OC. The transport of properties by the OC depends on the rate of overturning and the difference in property concentration between the upper and lower limbs of the overturning; in many locations, the horizontal gyres also contribute to the meridional transport of heat and other properties. Therefore observations of the OC must extend throughout the full depth and breadth of the ocean basins to quantify changes in the $\mathrm{OC}$ and to determine their cause and impact. This poses a significant challenge. Often observational estimates of the overturning depend on proxy techniques that allow the transport to be inferred from indirect, and more feasible, measurements.

Changes in the OC have been linked to past climate variations, including abrupt changes caused by a slowing of the OC, and climate models suggest the OC will both respond to and modulate climate change in the future (e.g. [1]). The OC and deep circulation also contribute to internal climate variability, on time-scales from decades and longer (e.g. [2]). For example, multi-decadal variability in Atlantic sea surface temperatures, known as the Atlantic Muli-decadal Oscillation (AMO), has been linked to regional climate trends, hemispheric temperature anomalies, hurricane activity and drought over parts of Africa including the Sahel ([3 and references therein]). There is growing consensus that a significant fraction of the lowfrequency variability in Atlantic SST (Sea Surface Temperature) is driven by variations in the OC [3].

In climate models, deep ocean heat uptake has been found to be well correlated with climate sensitivity, with greater ocean heat uptake implying a larger commitment to future warming and sea level rise [4 and 5]. In fact, the degree to which the deep ocean takes up heat may be the largest uncertainty in determining climate sensitivity [6]. A similar argument applies to the ocean uptake of carbon dioxide. Hence deep ocean measurements are central to reducing uncertainty in projections of global warming and sea level rise. Observations suggest that warming of the deep ocean has contributed about $20 \%$ of the total increase in ocean heat content over the last decade or so [7].

Biological activity transfers nutrients and carbon to the deep ocean as settling particles. Upwelling of deep water as part of the OC, particularly in the Southern Ocean, returns nutrients to the surface ocean to support phytoplankton growth [8]. Changes in the overturning circulation would therefore be expected to influence global primary productivity and ecosystem function [9]. Deep water is also rich in carbon and the efficiency with which the ocean sequesters carbon dioxide from the atmosphere depends on a balance between the outgassing from upwelled deep water and the physical and biological processes acting to transport carbon into the ocean interior [10]. As discussed above for ocean heat uptake, climate change projections will be highly sensitive to the rate of carbon uptake by the ocean in climate models. The introduction of carbon-rich deep water into the surface layer will also affect the carbon saturation state, with implications for marine ecosystems.

While time series measurements are sparse in the deep ocean, there is increasing evidence of changes in properties and circulation. The changes make a significant contribution to changes in the overall heat content of the ocean, and therefore sea-level rise. Anthropogenic carbon dioxide is also beginning to accumulate in the deep ocean, especially in the sinking regions. Efforts to track the evolving ocean inventory of heat, freshwater, carbon and other climate-relevant quantities must therefore include measurements of the ocean below $2000 \mathrm{~m}$.

In summary, many of the most urgent challenges society is facing cannot be addressed without understanding (and therefore observing) the overturning circulation and the deep ocean. These challenges include climate change; sea-level rise; cycles of floods and droughts driven by internal decadal variability; the global carbon cycle and the potential for climate feedbacks; and the future of biological productivity in the sea.

\section{RECENT PROGRESS IN OBSERVING AND UNDERSTANDING THE DEEP OCEAN AND OC}

Given that variations in the $\mathrm{OC}$ have been linked to climate changes in the past, the response of the OC to future climate change is an important issue. The previous generation of coupled climate models showed that the OC slowed down, and in some cases collapsed, with enhanced greenhouse gas forcing [11]. More recent coupled climate models suggest that the Atlantic OC is likely to weaken by about $25 \%$ by the end of the century [12] (Fig. 1). The models that perform best 
when compared with observations all weaken gradually over the coming century [13]. The figure also shows that there are large differences between the IPCC AR4 (Intergovernmental Panel on Climate Change, Fourth Assesment) models in terms of the magnitude, variability and sensitivity to change of the OC. The wide spread of results in Fig. 1 underscores the need for observations of the $\mathrm{OC}$, including time series, to test and improve climate models.

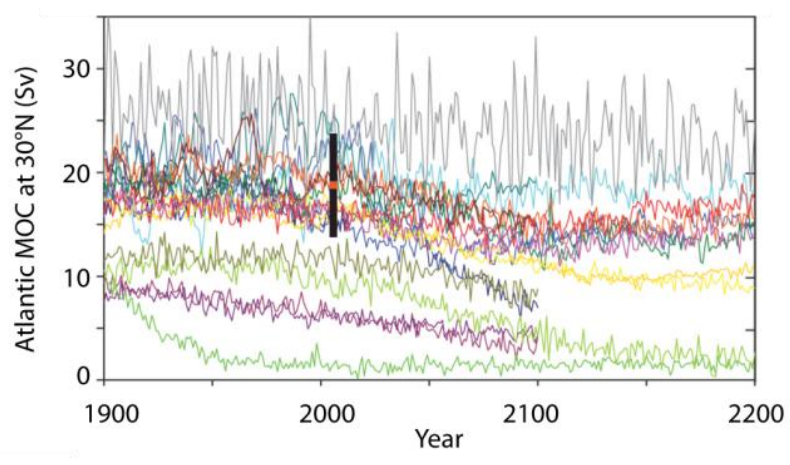

Figure 1. Evolution of the Atlantic meridional overturning circulation (AMOC) at $30^{\circ} \mathrm{N}$ in simulations with the suite of comprehensive coupled climate models from 1850 to 2100 using 20th Century Climate in Coupled Models (20C3M) simulations for 1850 to 1999 and the SRES AIB emissions scenario for 1999 to 2100. Some of the models continue the integration to year 2200 with the forcing held constant at the values of year 2100. Observational estimate of the mean AMOC and its variability observed at $26.5^{\circ} \mathrm{N}$ for 3.5 years from $1^{\text {st }}$ April 2004 (black bar). The mean AMOC for this period is $18.5 \mathrm{~Sv}$ with a standard deviation of \pm 4.9 Sv (for twice daily values). Three simulations show a steady or rapid slow down of the AMOC that is unrelated to the forcing; a few others have late-20th century simulated values that are inconsistent with observational estimates. Of the model simulations consistent with the late-20th century observational estimates, none shows an increase in the AMOC during the 21st century; reductions range from indistinguishable within the simulated natural variability to over $50 \%$ relative to the 1960 to 1990 mean. Adapted from [12].

\subsection{Observations of the overturning circulation}

Measuring the OC poses a significant challenge. The OC extends throughout the global ocean, reaches from the sea surface to the sea floor, and consists of both intense narrow boundary currents and broad flows in the ocean interior. In essence, measuring the OC and associated heat and freshwater transport requires observations of the global, full-depth, threedimensional, time-varying flow of the ocean. We do not yet have tools that allow us to do this directly.
Estimates of the global OC have therefore relied on indirect measurements. Hydrographic sections provide most of the information we have about the deep ocean. These sections can be combined with simple dynamical statements (e.g. geostrophy and conservation of mass) to estimate the overturning circulation using inverse methods or similar techniques. Fig. 2 illustrates the global overturning circulation inferred from a recent calculation [14 and 15]. The figure shows the familiar overturning in the Atlantic associated with the formation and export of North Atlantic Deep Water (NADW), balanced by northward flow of intermediate water and bottom water. The figure also illustrates the near-global extent of the OC, with deep water exported from the Atlantic circulating through the other ocean basins and returning in the upper ocean. (Fig. 8, discussed in Sect. 3, provides a different perspective of the global OC, highlighting the elements lost in a zonally-integrated view.) To understand the dynamics, transport and variability of the $\mathrm{OC}$, it is not possible to restrict attention to the North Atlantic. In particular, water mass transformations taking place in the Southern Ocean play an important role by connecting the upper and lower limbs of the OC, and dense water formed along the margin of Antarctica plays an equal role with NADW in ventilating the abyssal ocean [16]. An analysis of the global zonally-integrated ocean circulation from a data-constrained ocean state estimate found large decadal variability in the Southern Ocean [17]. Observations of other flow pathways (e.g. the Indonesian Throughflow, the southern hemisphere "supergyre," and deep boundary currents) are needed for a full understanding of the OC [18].

Hydrography-based estimates of the global OC [14, 19 and 20] are an impressive achievement, but have several weaknesses. They are usually based on a small number of widely-spaced sections taken at different times and rely on an assumption of a steady state ocean. Direct velocity measurements often do not exist to use as a reference for geostrophic calculations, and even if they do, are often aliased with tides or inertial motions or are representative of different spatial scales. The solutions are underdetermined and the true uncertainty of the estimate is difficult to estimate.

Ocean state estimates, based on assimilation of a variety of observations into a dynamical ocean model, potentially overcome a number of these drawbacks (e.g. [24 and 25]). Perhaps most importantly, ocean state estimates can provide estimates of the variability of the OC with time, consistent with both dynamics and observations. Impressive progress has been made in ocean state estimation in recent years, although some significant challenges remain, including model error, uncertain forcing fields, the lack of observations (with 
known errors) available for use as constraints, and computational demands (resulting in state estimates with either low spatial resolution, short duration, dynamically inconsistent assimilation approaches, or limited spatial domain) [24-26]. Solution of these issues will allow optimal use of observations and models in combination, as required, e.g., for inference of climate-relevant quantities that cannot be measured directly (e.g., heat transport variability). Ultimately our best estimates of the OC are likely to be derived from high resolution, data-assimilating models, but there is some way to go before this goal is reached. In particular, deep observations are essential, both as constraints and for model validation. Reference [27] showed that assimilating observations of the OC at $26.5 \mathrm{~N}$ (see below) improved the representation of the upper and lower limbs of the $\mathrm{OC}$ in an ocean state estimate over a latitude range of \pm 5 degrees of latitude of the observations. Reference [28] demonstrates the impact of assimilating deep hydrographic data at $26.5^{\circ} \mathrm{N}$ on estimates of the MOC strength.

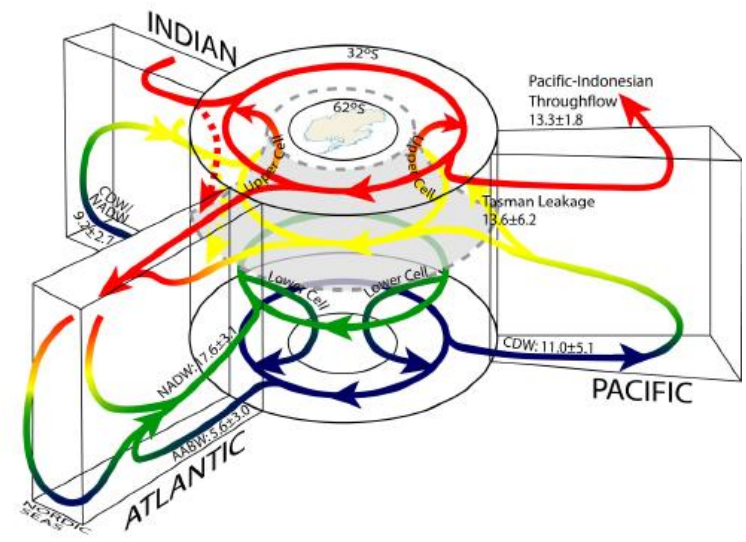

Figure 2: A schematic illustration of the global overturning circulation (from 14, after 21 and 22; see [23]).

While continuous, direct measurements of the global OC are not feasible, new approaches have been developed to allow monitoring of the OC at particular locations. An important achievement in the last decade is the first continuous, multi-year time series of the meridional mass transport contributing to the overturning circulation in the Atlantic sector.

The most ambitious example is the RAPID/MOCHA/WBTS (Research with Adaptive Particle Imaging Detectors/Meridional Overturning Circulation and Heat/Western Boundary Time Series) array at $26.5^{\circ} \mathrm{N}$ in the Atlantic being carried out by the UK and USA [29-31]. Fig. 3 shows a 3.5 year time series of the transport of individual components of the OC: the Gulf Stream at Florida Straits, interior flow in the upper ocean and Ekman transport. The mean overturning is $18.5 \mathrm{~Sv}$, with a standard deviation of 4.9 $\mathrm{Sv}$ and a standard error of $1.5 \mathrm{~Sv}$. The measurements reveal significant high frequency variability of the OC on several time-scales, underscoring the need for both continuous sampling to avoid aliasing and for long time series to detect trends. A previous study which used a sequence of hydrographic snapshots to infer a decline in the strength of the AMOC [32] now appear likely to have resulted from aliasing [31 and 33]. The continuous time series is providing new insights into the dynamics of the $\mathrm{OC}$, including identification of the mechanisms responsible for variability of the $\mathrm{OC}$ on different time-scales (e.g. [34]).

The RAPID/MOCHA/WBTS strategy for monitoring the MOC at $26^{\circ} \mathrm{N}$ consists of the following elements. The long term NOAA (National Oceanic and Atmospheric Administration) western boundary current program (WBTS) measures the Antilles Current and deep western boundary current (DWBC) using pressure-equipped inverted echo sounders (PIES) and electromagnetic measurements from a submarine cable. Dynamic height and bottom pressure moorings on either side of the deep basins and on either side of the mid-Atlantic ridge allow the pressure difference across the deep basins to be determined, from which the net transport can be derived using the geostrophic relationship. The Ekman transport is calculated from satellite scatterometer winds. The design was tested and refined using output from eddy-permitting ocean circulation models [35 and 36]. The fact that the sum of the individual components approximately conserves mass provides additional confidence that the transport estimates are robust [31].

The end-point monitoring approach has also proved effective at $16^{\circ} \mathrm{N}$ in the Atlantic in the Meridional Overturning Variability Experiment (MOVE), where the time series of North Atlantic Deep Water export is now more than nine years long [37 and 38]. Flows in the eastern basin contribute little to the net transport. The near-rectangular geometry of the western Atlantic basin allows the OC to be monitored with a small number of instruments and thus is very cost-effective. As found at $26.5^{\circ} \mathrm{N}$, the transport of the lower limb of the OC is highly variable on short time-scales (Fig. 4). Despite the large high frequency variability, the time series is of sufficient duration to detect a significant (at $85 \%$ ) weakening trend, corresponding to a $3 \mathrm{~Sv}$ reduction in the NADW export over the duration of the record. The weakening of the $\mathrm{OC}$ is consistent in magnitude with internal variability in the FLAME (Family of Linked Atlantic Model Experiments) model and with the OC reduction projected from a coupled model initialised with SST [39]. 


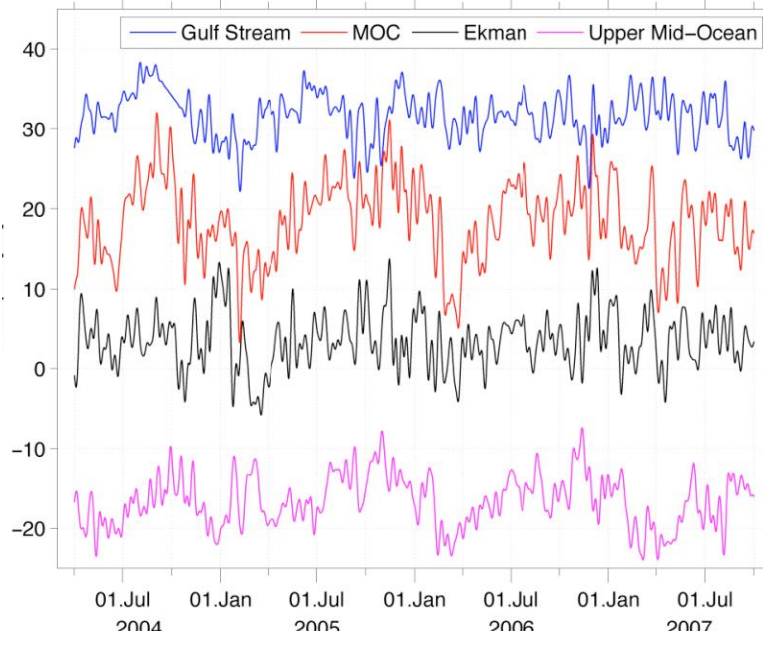

Figure 3. Twice daily time series of Florida Straits transport (blue), Ekman transport (black), upper midocean transport (magenta) and overturning transport (red). Transports in Sv, positive northward. Florida Straits transport is based on electromagnetic cable measurements. Ekman transport is based on QuikScat winds. The upper mid-ocean transport is the vertical integral of the transport per unit depth down to 1100 m. Overturning transport is the sum of Florida Straits,

Ekman and upper mid-ocean transport [30]. The mean \pm standard deviation of Gulf Stream, Ekman, upper-mid ocean and overturning transports are $31.7 \pm 2.8 \mathrm{~Sv}, 3.5 \pm 3.4 \mathrm{~Sv},-16.6 \pm 3.2 \mathrm{~Sv}$ and $18.5 \pm 4.9 \mathrm{~Sv}$ respectively.

The array design studies of [35 and 36] also identified locations where the end-point monitoring approach will not work. Where barotropic flows make a significant contribution to the mass and heat transport, they need to be measured. Where western boundary currents are broad (e.g. over sloping topography), extensive and expensive moored arrays may be required. Complex bathymetry and barotropic flows in the ocean interior also need to be resolved, for example in the subpolar gyre where the gyre circulation makes a significant contribution to the net heat flux. For accurate estimates of property transports, these measurements need to be horizontally coherent to capture the correlations of velocity and temperature that are responsible for heat transport.

Basin-integrals of the OC have only been observed directly and continuously at $26.5^{\circ} \mathrm{N}$ and $16^{\circ} \mathrm{N}$ in the Atlantic. But measurements of components of the OC of more than one year duration have now been made at several locations, in particular in dense overflows and along the deep western boundary current carrying NADW southward in the deep limb of the Atlantic MOC [29, 40 and 41]. These measurements have generally spanned the overflow or deep western boundary current, but not the flows in the interior of the basin. The presence of recirculation gyres offshore of the DWBC [42], usually not resolved by the moored arrays, often makes it difficult to use these measurements to infer the strength (or throughflow) of the OC [41]. However, they do provide robust estimates of a primary pathway of the deep limb of the overturning. The DWBC estimates can be combined with measurements in the ocean interior (e.g. hydrographic sections) to estimate the $\mathrm{OC}$ and net meridional transport. They also provide valuable constraints for ocean state estimates and for the testing of ocean models.
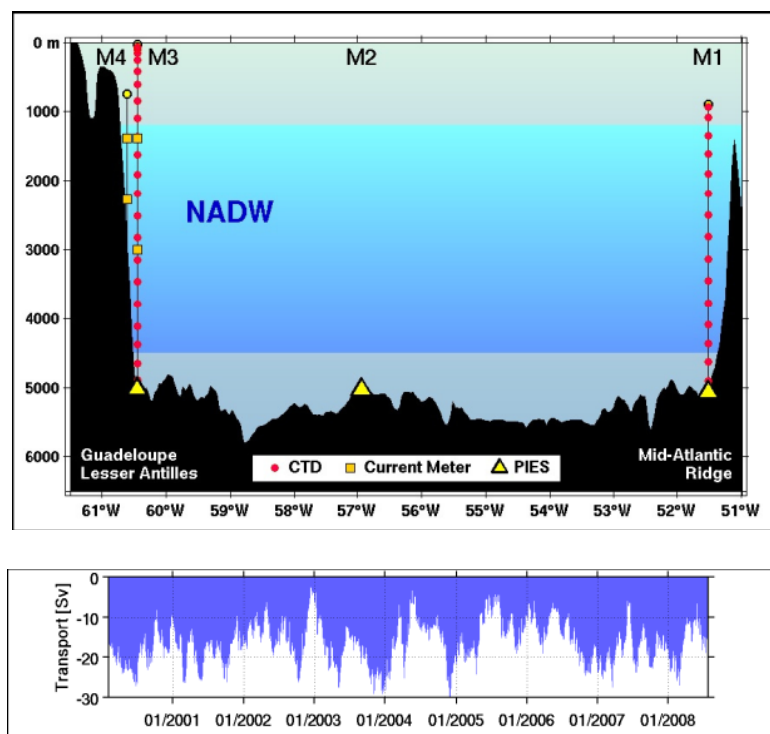

Figure 4. Top-MOVE section with endpoint moorings and PIES. Bottom - Absolute internal plus continental slope transport of NADW through the MOVE section from end-point moorings with density sensors. The long-term mean is 14.9Sv (southward) [38.]

Some current measurements have been made of the DWBC systems in the Indian and Pacific, but they are typically of less than two-year's duration and often lack the supplementary information needed to estimate the basin-wide overturning. As a consequence, estimates of the strength of the $\mathrm{OC}$ in the other ocean basins vary over a wide range [eg 19, 20, 43 and 44]. Examples include the DWBC carrying Antarctic Bottom Water (AABW) northward into the Argentine Basin [45], through the Vema Channel to the Brazil Basin [46], and crossing the equator to enter the North Atlantic [47]; the flow entering the Indian Ocean through the Madagascar [48] and Perth Basins [49]; and the Pacific DWBC at $30^{\circ} \mathrm{S}$ [50], the Samoa Passage [51] and at $5^{\circ} \mathrm{N}$ [52]. A recent study has directly measured the mean transport of the DWBC carrying AABW northward on the eastern flank of the Kerguelen Plateau (Fig. 5, [53]). Two-year mean flows of more than $20 \mathrm{~cm} \mathrm{~s}^{-1}$ were found at $3500 \mathrm{~m}$ depth, 
carrying 12.3 Sv northward (standard error of $1.2 \mathrm{~Sv}$, standard deviation of $5.6 \mathrm{~Sv}$ ), with $6.0 \mathrm{~Sv}$ returning southward across the eastern end of the array. The results indicate that the Kerguelen DWBC makes a significant contribution to the global OC.

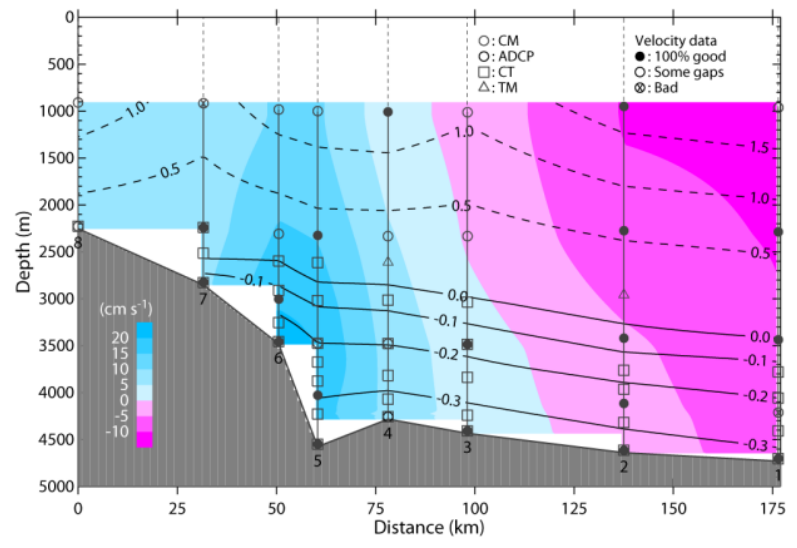

Figure 5. Kerguelen DWBC mean sections of the velocity perpendicular to the mooring array (shading; positive northwestward) and potential temperature (contours) over the two-year deployment. Also shown is a schematic diagram of moorings. CM, CT and TM denote current meter, conductivity-temperature recorder and thermistor. [53]

\subsection{Influence of the deep ocean and OC on global biogeochemical cycles}

The OC plays an important role in the global cycles of carbon, nutrients and other properties. Biological processes tend to transfer carbon and nutrients from the surface to the deep ocean. As a result, the deep ocean accounts for more than half of the natural oceanic carbon inventory. Mixing and the upwelling limbs of the OC return carbon and nutrients to the surface layer, where nutrients can support phytoplankton growth. The introduction of carbon-rich deep water to the surface layer affects air-sea exchange and the chemistry (e.g. $\mathrm{pH}$ ) of the upper ocean. For example, models suggest that nutrients upwelled and exported by the Southern Ocean support $75 \%$ of global primary production north of $30^{\circ} \mathrm{S}$ [8]. Changes in the OC would therefore be anticipated to have an impact on biological productivity [9] and the ocean uptake of $\mathrm{CO}_{2}$. Atmospheric observations and coarse-resolution ocean model studies have suggested that the carbon sink in the Southern Ocean has "saturated" in recent decades, as a result of an increase in strength of the overturning circulation (and hence increased outgassing of natural carbon from the deep ocean) in response to stronger winds [10]. This result, however, may significantly change when ocean eddy feedback processes are resolved [54].
The sinking of surface waters in the downwelling limbs of the OC transfers anthropogenic $\mathrm{CO}_{2}$ to the deep ocean. While most of the oceanic inventory is found in the upper ocean, anthropogenic $\mathrm{CO}_{2}$ is beginning to invade the deep sea in deep water formation areas. For example, Fig. 6 shows that anthropogenic $\mathrm{CO}_{2}$ is present in the deep waters of the North Atlantic. Anthropogenic $\mathrm{CO}_{2}$ has also been observed in deep waters formed in the Southern Ocean [58-60]. As the deep ocean burden increases with time, it will become increasingly important to measure the deep ocean to track the evolving inventory of anthropogenic $\mathrm{CO}_{2}$, particularly near the deep water formation zones and export pathways. Estimating anthropogenic $\mathrm{CO}_{2}$ in the ocean depends on empirical techniques, many of which rely on simultaneous measurements of other tracers, such as CFCs (chlorofluorocarbon) [61]. Therefore it is essential that hydrographic sections include transient tracers such as CFCs and $\mathrm{SF}_{6}$ as well as measurements of the carbon system.

\subsection{Influence of the deep ocean and OC on low- frequency climate variability}

Seasonal and interannual climate variability is largely independent of the deep ocean and OC. But as the time-scale of climate variability increases, the deep ocean becomes an increasingly important player. Multidecadal variations in Atlantic sea surface temperature (SST) have been linked to a wide range of phenomena of direct interest to society, including regional climate anomalies, persistent drought, hurricane frequency and fisheries production (see [3, 62 and 63] and references therein). A number of recent studies, summarised in [2], show that SST variations on this time scale are influenced by the OC. In particular, recent work (e.g. [64]) supports the conclusion of Bjerknes [65] that at these time-scales ocean dynamics tend to dominate, and therefore ocean observations may help to realize some potential predictability. Estimates of the potential predictability of decadal variability tend to be large where the $\mathrm{OC}$ is significant, in the North Atlantic and Southern Ocean [2]. While our dynamical understanding of lowfrequency climate variability remains incomplete, a number of studies have concluded that advection of salinity anomalies by the OC can also result in decadal variability of the $\mathrm{OC}$ and its heat transport, and therefore in anomalies of sea surface temperature that drive decadal variability in the overlying atmosphere [e.g. 62].

Decadal predictions would be of great value to society, for example by providing advanced warning of periods of drought. Improvements in this young field will require a more complete understanding of the dynamics of the OC and deep ocean and their links to the 
atmosphere. An important point is that climate prediction at these time-scales becomes a joint initial value/boundary value problem, requiring accurate data with which to initialise the climate state, in particular the ocean [2], in addition to prescribing future greenhouse gas and aerosol emission scenarios. Sustained observations of the deep ocean and OC are needed to make progress on decadal prediction [66]. Preliminary studies by the Hadley Centre have shown that temperature observations below 2000m improve decadal forecasts of ocean heat content change [67 and 68].

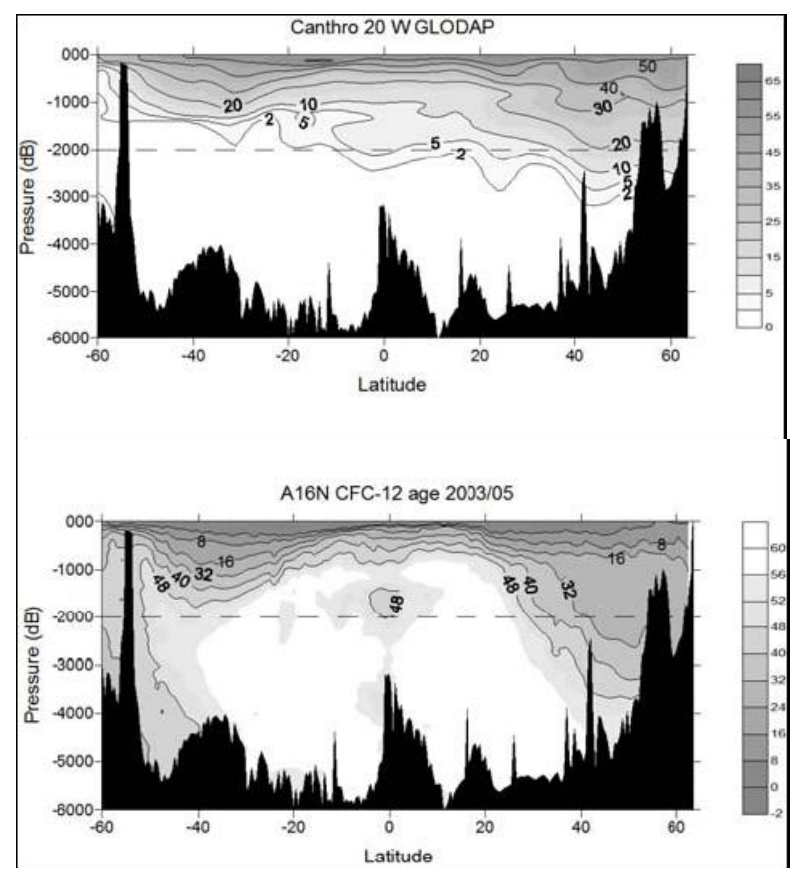

Figure 6. Top: Anthropogenic $\mathrm{CO}_{2}$ levels along $20^{\circ} \mathrm{W}$ in the Atlantic Ocean. The data are from the Global Ocean Data Analysis Project (GLODAP) synthesis product based on the World Ocean Circulation Experiment (WOCE) cruises in the 1990's, [55].

Bottom: Chlorofluorocarbon-12 (CFC-12) age section in the North Atlantic (nominally $20^{\circ} \mathrm{W}$ ) based on observations on the CLIVAR/CO $\mathrm{O}_{2}$ (Climate Variability and Predictability/carbon dioxide) cruises A16N and A16S in 2003 and 2005, respectively [56]. The figures show the anthropogenic imprint penetrating to depths greater than $2000 \mathrm{~m}$. (From [57]).

\subsection{Observations of change in the deep ocean}

The lack of time series measurements has in the past prevented studies of change in the deep ocean. Recent analyses of data collected by the repeat hydrography program [69] are starting to reveal larger than anticipated signals of change in the deep ocean. The changes in deep ocean properties indicate that at least in some regions the deep ocean can respond rapidly to changes in surface climate.

The Australian Antarctic Bottom Water (AABW) exported from the Southern Ocean to ventilate the abyss of each ocean basin has warmed in recent decades [7, 70-75]. An example from the Atlantic is shown in Fig. 7. The changes in deep ocean temperature are sufficient to account for a significant fraction of the global energy imbalance [68, 72, 76 and 77]. Reference [7] has estimated that the warming below 4000m depth and below $1000 \mathrm{~m}$ south of the Subantarctic Front contributes about $0.09 \mathrm{~W} \mathrm{~m}^{-2}$ to the global heat budget (compared to $0.5 \pm 0.18 \mathrm{~W} \mathrm{~m}^{-2}$ for the 0-700 m layer of the ocean [78]). This contribution to the planetary energy budget will grow in importance as the anthropogenic warming signal propagates to increasing depth with time. The warming below 4000

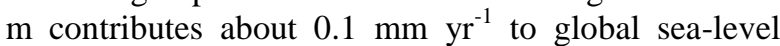
rise, while the warming below $1000 \mathrm{~m}$ in the Southern Ocean contributes about $1 \mathrm{~mm} \mathrm{yr}^{-1}$ of sea-level rise there. These new studies complement previous results [76, 79 and 80], indicating significant warming between 700 and $3000 \mathrm{~m}$ in the North Atlantic Ocean.

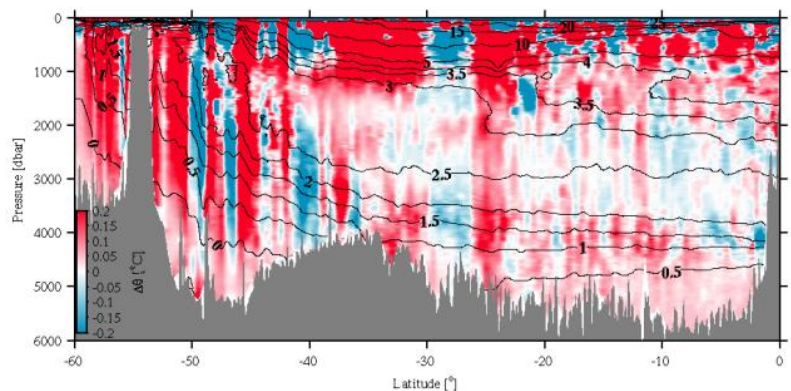

Figure 7. Differences in potential temperature, $\Delta \Theta$ $\left[{ }^{\circ} \mathrm{C}\right]$, in the western South Atlantic resulting from subtracting WOCE section A16 data taken in 1985 (and A23 in 1995 in the Scotia Sea, south of $54^{\circ} \mathrm{S}$ ) from 2005 reoccupation data taken by the U.S.

CLIVAR/CO2 Repeat Hydrography Program. Values of $\Delta \Theta$ are color contoured (inset color bar) from -

$0.2^{\circ} \mathrm{C}$ to $+0.2^{\circ} \mathrm{C}$ to accentuate deep changes. Mean $\theta$ is contoured (black lines) at $0.5^{\circ} \mathrm{C}$ intervals below

$15^{\circ} \mathrm{C}$, and $5^{\circ} \mathrm{C}$ intervals above $15^{\circ} \mathrm{C}$. Abyssal warming in the Scotia Sea, Argentine Basin, and Brazil Basin reaches $0.04^{\circ} \mathrm{C}$, equivalent to $0.5 \mathrm{~W} \mathrm{~m}^{-2}$ heating along the section to account for the warming at pressures exceeding 3000 dbar. After [70].

The possibility that increased freshwater input to the high latitude ocean could cause a slowing of the thermohaline circulation and changes in climate has focused considerable interest on the high latitude freshwater budget. Changes in upper ocean salinity have been observed in each of the ocean basins, with an increase in salinity in the subtropical evaporation 
zones and a decrease at higher latitudes that is consistent with a more vigorous hydrological cycle and increased supply of melt water at high latitudes [78 and 81-83]. Numerous studies documented a freshening of North Atlantic Deep Water between the mid-1960s and the mid-1990s, when the North Atlantic Oscillation (NAO) evolved to an extreme positive state (e.g. [84]). The freshening reversed in the mid-1990s. Weakening of westerlies associated with the NAO decline in the mid-1990s to mid-2000s caused a reduction of convection intensity in the Labrador Sea, a slowing and contraction of the subpolar gyre, and the northward advance of warm saline subtropical waters [85-90]. The NAO-induced upper ocean changes were rapidly transferred to deeper levels, causing an increase in temperature and salinity of Labrador Sea Water (LSW) and the deep waters [91-93].

While measurements are sparse in the Southern Ocean, several recent studies have detected changes in the salinity of Antarctic Bottom Water [71, 94-99]. The Ross Sea and Adélie Land regions supply about $40 \%$ of the total input of AABW [16]. Most of the AABW exported from both sources passes through the Australian Antarctic Basin, making it a good place to monitor changes in properties of the AABW formed in the Indian and Pacific sectors. The deep $\theta-S$ relationship has changed throughout the basin in recent decades, with a shift toward fresher and lighter bottom water observed in the deepest $1000 \mathrm{~m}$ of the water column [99]. References [96, 100 and 101] suggest that the most likely source of the additional freshwater is basal melt of glacial ice in the Pacific sector. Enhanced basal melting there has been linked to warmer ocean temperatures [102]. In contrast, in the Weddell Sea the situation is ambiguous, with freshening of bottom water in the west [103] and a slight increase in the salinity of deep water in the east [74].

The evidence from the North Atlantic and the Southern Ocean suggests that the dense water sinking in both hemispheres is responding to changes in the high latitude freshwater balance, and is rapidly transmitting this climate signal to the deep ocean. However, in only a few places are the observations sufficiently frequent to avoid aliasing of interannual variability. Expanded arrays of continuous measurements of deep ocean properties are needed to better understand the OC and its response to changes in forcing.

\section{A STRATEGY FOR SUSTAINED OBSERVATIONS}

The deep ocean remains essentially unmeasured by the present ocean observing system, at least in a continuous sense. Most of our information comes from deep hydrographic sections, few of which have been repeated to allow assessments of change. Those sections that have been repeated are often separated in time by years or decades and hence are prone to aliasing. The distance between different repeat lines is typically 1000 s of $\mathrm{kms}$, so the spatial scale of property anomalies is poorly resolved. Continuous time series spanning a few years have been obtained in several current systems, with most in the dense overflows and DWBC of the North Atlantic. Our present understanding and observations of the deep ocean and $\mathrm{OC}$ are inadequate to carry out a rigorous process of setting priorities and evaluating trade-offs. No systematic observing system design studies have yet been carried out for the global OC and deep inventory. Nevertheless, substantial progress has been made in recent years, as summarised below and in [29] and [57] (for example, Tab. 1 of [29] lists 25 individual contributions measuring components of the Atlantic OC). A challenge for the community in the coming years is to make the transition from a collection of observing elements to an integrated, coherent observing system. New technologies are also essential. In the following we outline a strategy for initial steps towards this goal.

The scientific challenges to be addressed with deep ocean observations require measurements of both transport and inventory. The sampling needs of each are different and it is useful to consider them in turn when designing a strategy for sustained observations of the ocean. In each case, we have considered the relevance, feasibility, cost-effectiveness and readiness of each component in reaching our recommendations.

\subsection{An observing system for the transport of the OC and deep circulation}

Sustained time series measurements of the transport of the OC and deep currents rely on use of a combination of approaches.

- Boundary Currents: Much of the transport of the $\mathrm{OC}$ is carried in narrow boundary currents and therefore direct velocity measurements are needed there [37]. Both the surface-intensified but deepreaching western boundary currents of the subtropical and subpolar gyres, and the deep western boundary currents that dominate the abyssal flow need to be measured. Boundary current transports can be observed using current meter arrays incorporating point-measurements and profiling acoustic Doppler current profilers (ADCPs), cables, pressure gauges and PIES.

- Volume transport in the interior: The full-depth volume transport in the interior of deep basins can be inferred from deep hydrographic measurements 
near the end-points (from moorings, ships, gliders or in some cases PIES), using the geostrophic relationship. Additional measurements are needed over the sloping topography at the basin boundaries or mid-ocean ridges.

- Property transport in the interior: Estimates of the transport of properties (e.g. heat, freshwater, carbon) require knowledge of the covariance between velocity and concentration and cannot, in general, be made from end-point measurements alone. Given the prohibitive cost of a coherent "picket fence" of tall moorings spanning ocean basins (and the lack of moored sensors for some properties of interest), repeat hydrographic sections are in most cases the only approach available for estimating property fluxes over the full ocean depth. In some locations, where a close relationship exists between an integral property (e.g. acoustic travel time) and a single mode of variability of vertical profiles of temperature and salinity [104], property fluxes can be measured using a coherent array of C-PIES. In the future, Argo floats and gliders capable of profiling the deep ocean will contribute to this goal, as will longduration moorings to provide measurements of bottom pressure and/or currents to constrain the barotropic flow.

- Ekman transport: Can be estimated from satellite scatterometer measurements of wind stress (and therefore scatterometers are an important part of an OC observing system).

- Altimetry and gravity: Measurements from space provide additional constraints on the flow and are useful for monitoring the OC (as well as changes in ocean mass relevant to ocean-cryosphere interaction) [105].

- Synthesis: analysis approaches such as inverse methods or state estimation are often required to combine the observations in a consistent manner, in particular where observations resolve only a component of the OC.

\subsection{An observing system for deep ocean inventories}

Measurements of the evolving inventory of heat, freshwater, carbon and other properties rely heavily on deep repeat hydrography [69]. Hydrographic sections remain the only tool available to sample the deep ocean over broad scales and the only way to collect samples for biological and biogeochemical analyses. The signal of change will appear first and be most prominent near the dense water overflows and along the main pathways of the deep circulation, hence these areas need to be sampled more frequently. Moored instruments provide the only means to obtain continuous time series of ocean currents and water properties and are therefore a key part of the armoury, despite the relatively high cost and therefore limited spatial distribution [106]. Repeat glider transects can also contribute to this goal. Altimetry and gravity measurements provide integral constraints on ocean heat content. Acoustic tomography/thermometry also provides useful integral constraints on ocean heat content [107]. However, each of these tools has limitations and as a result, we are still not in a position to measure accurately changes in full-depth ocean heat content and other properties over most of the ocean. New technologies are urgently needed to allow routine sampling of the deep ocean and estimation of a true global integral of ocean heat and freshwater content from the surface to the sea floor. Floats and gliders capable of profiling through the full ocean depth would provide the greatest leap forward in our capability to sample the deep ocean.

\subsection{Specific recommendations:}

The initial strategy for sustained observations of the OC and deep ocean is summarised in Fig. 8. Further detail is available in the relevant Community White Papers and Plenary Papers (in particular [18, 29, 57, 69 and 106]). Fig. 8 also illustrates the complex global network of deep boundary currents, basin-scale gyres, and interbasin exchanges that make up the OC.

To understand the response of the OC and associated property transports to changes in forcing, measurements are needed at several latitudes to allow the meridional coherence of the $\mathrm{OC}$ to be assessed and understood. The partitioning of the meridional heat transport between the overturning and horizontal gyre circulations, for example, differs strongly with latitude [108]. Model studies suggest that the meridional coherence of the AOC has different timescales at different latitudes, with stronger decadal variability in the subpolar regime and stronger high frequency variability in the subtropics [109 and 110]. Other model studies suggest that measurements at a single latitude in each basin of the Atlantic might be sufficient to detect OC changes on multidecadal scales, but that measurements at additional latitudes are needed to capture interannual to decadal variability and to understand the role that inter-ocean and interbasin exchanges play in the OC and climate [108 and 111]. 


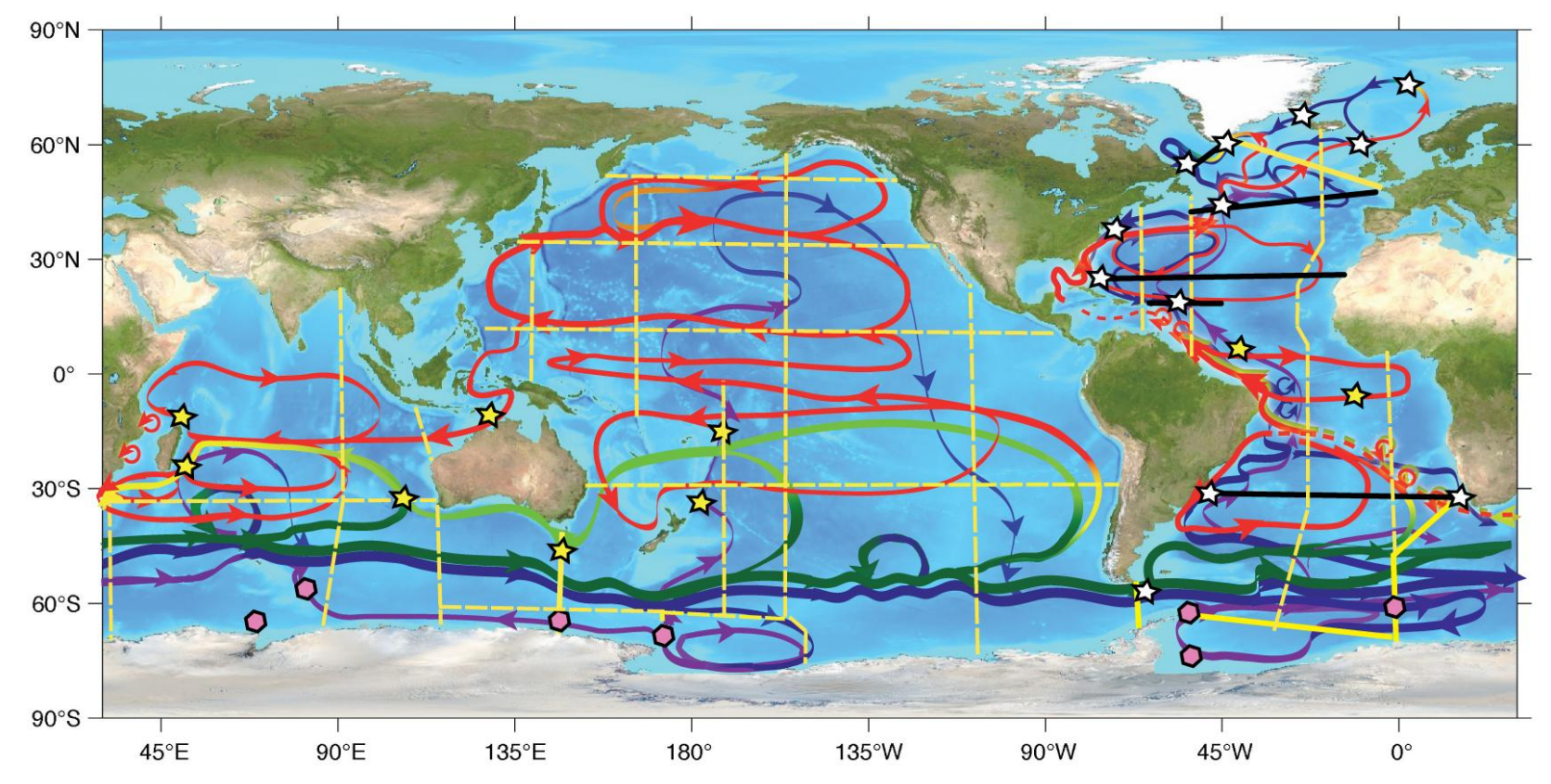

Figure 8. Schematic of the global ocean overturning circulation. Red indicates upper ocean flow, blue and purple are deep flows, and yellows and greens represent transitions between depths. The proposed observing system includes: repeat hydrography (dashed yellow lines; solid bold yellow lines indicate higher frequency repeat lines); basin-scale arrays of moorings and repeat hydrography for main transport lines (bold black lines); moored arrays across deep

boundary currents and interbasin exchanges (stars) and in the primary AABW outflows (hexagons). White stars indicate locations of existing arrays; yellow stars indicate recommended new arrays. For clarity, some components of the proposed observing system are omitted (e.g. floats and broad-scale mooring array, see [57].) Base map from S. Speich, adapted from R. Lumpkin.

Based on these results, basin-wide monitoring of the Atlantic OC and meridional heat and freshwater transport is recommended at a minimum of three latitudes: $47^{\circ} \mathrm{N}, 26.5^{\circ} \mathrm{N}$ and between $25-35^{\circ} \mathrm{S}$. At $26.5^{\circ} \mathrm{N}$, the RAPID/MOCHA array needs to be maintained. At $47^{\circ} \mathrm{N}$ and $35^{\circ} \mathrm{S}$, interior measurements of water properties and velocity are needed, as well as boundary arrays and end-point monitoring. A pilot array of PIES and CPIES (Current and Pressure recording Inverted Echo Sounders) has been deployed at the eastern and western boundaries at $35^{\circ} \mathrm{S}$ and its continuity and enhancement is recommended. Closure of the Labrador Basin with a full-depth transport and flux array is also recommended to monitor the production and export of Labrador Sea Water, an important contributor to the Atlantic MOC and a region known to be sensitive to climate variability such as the North Atlantic Oscillation.

The basin-wide monitoring needs to be complemented with measurements of key components of the OC and deep circulation. Existing long-term measurements of dense overflows and boundary currents in the Atlantic must be continued (see Fig. 3 and Tab. 1 of [29] for the location of these measurements). A new array is needed at Cape Farewell to measure the combined flux of the Denmark Strait and Faroe Bank Channel overflows [112]. Monitoring of the boundary currents in the South Atlantic needs to be enhanced [57]. The Southern Ocean chokepoint sections and Indonesian Throughflow need to be monitored to determine the influence of interbasin exchange on the OC [18, 113 and 114]. Dense water formed in the Southern Ocean plays a roughly equal role in ventilating the deep ocean [15 and 16] and therefore the southern hemisphere dense overflows and boundary currents carrying ventilated water northward also need to be measured for a complete understanding of the global OC [115].

Repeat hydrography will remain the backbone of the broad-scale deep ocean observing system [69]. The recommended repeat hydrographic lines are shown in Fig. 8; these lines have been identified as high priority by GO-SHIP (Global Ocean Ship-based Hydrographic Investigations Program) and commitments for future occupations exist for most of these sections. On each section, top-to-bottom measurements of temperature, salinity, oxygen, carbon, nutrients and transient tracers are needed. More frequent sections are recommended near the dense water overflows and boundary currents, where the signal of change is evolving more rapidly 
(see [69] for the rationale and recommended sampling frequency for specific sections).

The repeat hydrography program, while essential, is still far from adequately sampling the deep ocean, given the infrequent sampling in space and time. The OceanSITES (OCEAN Sustained Interdisciplinary Time series Environment observation System) network of long-term time series stations will make an important contribution [106] and needs to be wellintegrated with other deep-ocean observing systems. Acoustic thermometry is a valuable and cost-effective complement to deep hydrography, capable of providing basin-wide integrals of heat content that include the deep ocean, as well as measurements of ocean currents [107].

In addition to maintaining the existent observing systems for deep ocean velocity, heat, salt, and carbon there is a critical need to develop new, cost-effective, technologies for observing the deep ocean. Profiling floats capable of deeper profiling would allow broadscale, sustained sampling of deep ocean properties for the first time. As well as the technological advances necessary to achieve this, design studies are needed urgently to determine the appropriate investment and deployment strategy for deep floats. Deep gliders could also make an important contribution and prototypes are being tested now that are designed to profile to $6000 \mathrm{~m}$ depth. Near-continuous time series are needed to avoid aliasing and to determine the spectrum of deep variability. As mentioned above, the OceanSITES network will make a significant contribution to this goal. Development of long-term moorings with the ability to transfer data to the surface (e.g. using expendable data capsules, acoustics or other means) is needed to allow time series to be measured in remote ocean locations in a cost-effective manner [57]. Development of new sensors and platforms to measure carbon and other biogeochemical parameters is essential to improve our ability to track the evolving ocean inventory of carbon and acidification.

An observing system for the overturning circulation also depends heavily on elements of the global ocean observing system covered in detail by other Community White Papers and Plenary Papers in this volume, including Argo, boundary current measurements and satellite remote sensing (e.g. altimetry, gravity, infrared and microwave SST, scatterometer and cryosphere). Measurements of the upper ocean are clearly important to a full understanding of the overturning circulation, but these are covered in detail elsewhere in this volume. Closer links also need to be made to the geophysical community who are installing sea-floor observatories at a number of locations around the globe.

\subsection{Readiness}

The observing system depicted in Sect. 8 is at various stages of readiness and commitment. The repeat hydrography lines have been carefully considered by the GO-SHIP community and most of these lines have commitments for ongoing repeats, with a repeat time of five to ten years. Several lines at high latitude are being repeated more frequently (indicated as solid lines in Fig. 8; see [69] for details). The moored arrays identified in Fig. 8 are, from a technology standpoint, ready to go now. More than 20 moored arrays and repeat lines have already been established in the Atlantic basin, as described in more detail in [29]. Many of these have a multi-year commitment. Each of the Southern Ocean sites identified by hexagons in Sect. 8 has been sampled with a moored array of at least one-year duration in the last decade. The three Weddell Sea sites have been maintained for more than eight years and are still underway. There are fewer established, long-term moored arrays in the other ocean basins, although pilot experiments are planned or are underway for most of the sites indicated in Fig. 8. OceanSITES now has nearly 100 open-ocean, longterm sites, mainly moorings, with additional sites being added.

Overall, a large fraction of the recommended observing system for the deep ocean and OC already exists or is being developed - in particular, those components that rely on existing technology. On the other hand, the tools available today leave vast blind spots in the deep observing system: we have no means of making broadscale, sustained measurements of the properties and circulation of the deep ocean. Three particular elements that are under development would make this possible: floats capable of profiling throughout the full ocean depth; gliders capable of full-depth, basin-scale missions; and long-endurance moorings with data telemetry capability. For the non-physical parameters, new sensors are urgently needed.

Another aspect of "readiness" is the extent to which the community has developed and articulated a common view of what is needed to address the science challenges of highest priority. In this regard, the community-wide consultation carried out through OceanObs'09 and reflected here is perhaps a first step, rather than the end point. Further work is required by the community to integrate and optimise the global array of observations of the deep ocean and overturning circulation. Rigorous and quantitative evaluations of the deep observing system are required. 


\section{SUMMARY OF RATIONALE AND RECOMMENDATIONS}

Sustained observations of the deep ocean are needed to address key uncertainties that limit our ability to respond effectively to climate change and variability. In particular, deep observations are needed to:

- determine the transport (mass, heat, salt, and carbon), variability, dynamics and climate influence of the $\mathrm{OC}$;

- close the planetary energy budget;

- determine the rate and mechanisms of sea-level rise;

- determine the global budgets of carbon and nutrients, their sensitivity to change and the impacts of changing ocean chemistry on deep-sea biota;

- constrain ocean state estimates;

- initialise decadal climate forecasts;

- understand the dynamics and nature of the globalscale ocean circulation, including the response to forcing and modes of variability; and

- test and develop models, proxies and satellite data.

Sustained observations of the deep ocean remain a significant challenge. However, recent advances provide some guidance for the design of a deep ocean observing system. Our recommendations for deep ocean observations are summarised in Sect. 8 and can be grouped in four categories: general strategy; existing observations that need to be maintained; observations that are ready now, but are not yet being made; and observations that require the development of new technology.

\section{General recommendations:}

- As a starting point, maintain and build on established sites and technologies.

- Carry out further observing system evaluation studies to refine the design of the deep ocean observing system.

- Enhance the coordination of deep observations, to ensure resources are deployed as effectively as possible.

\section{Maintain:}

- Continue existing moored arrays in key deep boundary currents and passages (e.g. $26.5^{\circ} \mathrm{N}, 16^{\circ} \mathrm{N}$, dense water outflows in the North Atlantic and Southern Ocean).

- Repeat full-depth hydrography with tracers (with more frequent measurements near dense water outflows).

- Argo observations in the upper ocean, which help to constrain the transport of the upper limb of the overturning circulation.
- Satellite observations (altimeter, gravity), which measure integrals of the water column and are therefore an important component of a deep ocean observing system.

Enhance, using technology available now:

- Design and implement monitoring arrays at $47 \mathrm{~N}$ and between 25-35S in the Atlantic and in the main deep water flow pathways in other basins, as shown in Fig. 8. Design studies are needed to guide the strategy at each location.

Develop:

- Develop and deploy deep Argo floats to obtain broad-scale sampling of deep ocean properties.

- Develop and deploy gliders capable of deep, long duration missions.

- Develop and deploy moorings capable of providing long-term, continuous time series of deep ocean properties on basin scales. Make use of existing OceanSITES platforms, and develop data telemetry.

- Expand the use of acoustic tomography and thermometry to provide integral constraints on ocean heat content and ocean currents.

\section{REFERENCES}

1. Alley R. B., J. Marotzke, W. D. Nordhaus, J. T. Overpeck, D. M. Peteet, R. A. Pielke Jr., R. T. Pierrehumbert, P. B. Rhines, T. F. Stocker, L. D. Talley, J. M. Wallace (2003). Abrupt Climate Change, Science, Vol. 299.

2 Latif, M. \& Co-Authors (2010). "Dynamics of Decadal Climate Variability and Implications for its Prediction" in these proceedings (Vol. 2), doi:10.5270/OceanObs09.cwp.53.

3. Hurrell, J. \& Co-Authors (2010). "Decadal Climate Prediction: Opportunities and Challenges" in these proceedings (Vol. 2), doi:10.5270/OceanObs09.cwp.45.

4. Raper, SCB; Gregory, JM; Stouffer, RJ, 2002. The role of climate sensitivity and ocean heat uptake on AOGCM transient temperature response. J. Clim., 15, 124-130.

5. Meehl, GA; Washington, WM; Collins, WD, et al., 2005. How much more global warming and sea level rise? Science, 307, 1769-1772.

6. Boe, J; Hall, A; Qu, X, 2009. Deep ocean heat uptake as a major source of spread in transient climate change simulations. Geophys. Res. Lett., 36, L22701.

7. Purkey, S. G., and G. C. Johnson. 2010. Antarctic Bottom Water warming between the 1990s and the 2000s: Contributions to global heat and sea level rise budgets. Journal of Climate, submitted.

8. Sarmiento, J.L., High-latitude controls of thermocline nutrients and low biological productivity. Nature, 2004. 427: p. 56-60. 
9. Schmittner, A., Decline of the marine ecosystem caused by a reduction in the Atlantic overturning circulation. Science, 2005. 343: p. 628-633.

10. Le Quéré, C. et al. Saturation of the Southern Ocean $\mathrm{CO} 2$ sink due to recent climate change. Science 316, 1735-1738, doi:10.1126/science.1136188 (2007).

11. Gregory, J. M., K. W. Dixon,R. J. Stouffer,A. J. Weaver, E. Driesschaert, M. Eby, T. Fichefet, H. Hasumi, A. Hu, J. H. Jungclaus, I. V. Kamenkovich, A. Levermann, M. Montoya, S. Murakami, S. Nawrath, A. Oka, A. P. Sokolov, R. B. Thorpe, (2005). A model intercomparison of changes in the Atlantic thermohaline circulation in response to increasing atmospheric $\mathrm{CO} 2$ concentration. Geophys. Res. Lett., 32, L12703, doi:10.1029/2005GL023209.

12. IPCC, ed. IPCC, 2007: Climate Change 2007: The Physical Science Basis. Contribution of Working Group I to the Fourth Assessment Report of the Intergovernmental Panel on Climate Change. ed. S. Solomon, D. Qin, M. Manning, Z. Chen, M. Marquis, K.B. Averyt, M. Tignor and H.L. Miller. Vol. ISBN 9780521 88009-1 Hardback; 9780521 70596-7 Paperback. 2007, Cambridge University Press: Cambridge, United Kingdom and New York, NY, USA. 996.

13. Schmittner, A, Latif, M, Schneider, B 2005. Model projections of the North Atlantic thermohaline circulation for the 21 st century assessed by observations. Geophys. Res. Lett., 32, 2, L23710, doi:10.1029/2005GL024368.

14. Lumpkin, R., and K. Speer, (2007). Global Ocean meridional overturning. Journal of Physical Oceanography, 37(10):2550-2562.

15. Lumpkin, R., K. Speer, and K.P. Kolterman, (2008). Transport across 48 degrees $\mathrm{N}$ in the Atlantic Ocean. Journal of Physical Oceanography, 38(4), 733-752.

16. Orsi, A.H., W. M. Smethie and J. B. Bullister, (2002), On the total input of Antarctic waters to the deep ocean: A preliminary estimate from chlorofluorocarbon measurements. J. Geophys. Res., 107(C8), 3122.

17. Wunsch, C. and P. Heimbach, 2009: The globally integrated ocean circulation (OC), 1992-2006: seasonal and decadal variability. J. Phys. Oceanogr., 39(2), 351-368, doi:10.1175/2008JPO4012.1.

18. Gordon, A. \& Co-Authors (2010). "Interocean Exchange of Thermocline Water: Indonesian Throughflow; "Tassie" Leakage; Agulhas Leakage" in these proceedings (Vol. 2), doi:10.5270/OceanObs09.cwp.37.

19. Ganachaud, A. and C. Wunsch (2000).Improved estimates of global ocean circulation, heat transport and mixing from hydrographic data. Nature, 408(6811): p. 453-457.

20. Talley, L.D., J.L. Reid, and P.E. Robbins 2003). Databased Meridional Overturning Streamfunctions for the Global Ocean. J. Clim., 16(4): 3213-3226 Doi:10.1175/2787.1.

21. Gordon, A.L., 1991. The role of thermohaline circulation in global climate change. In: LamontDoherty Geological Observatory 1990 \& 1991 Report, Lamont-Doherty Geological Observatory of Columbia University, Palisades, New York, pp. 4451.

22. Schmitz Jr., W.J., 1996a. On the World Ocean Circulation: Volume I, Some Global Features/North Atlantic Circulation. Woods Hole Oceanographic Institution Technical Report WHOI-96-03, 141 pp.

23. Richardson, P. L. 2008, On the history of meridional overturning circulation schematic diagrams. Progress in Oceanography 76: 466-486.

24. Stammer, D. \& Co-Authors (2010). "Ocean Information Provided Through Ensemble Ocean Syntheses" in these proceedings (Vol. 2), doi:10.5270/OceanObs09.cwp.85.

25. Lee, T. \& Co-Authors (2010). "Ocean State Estimation for Climate Research" in these proceedings (Vol. 2), doi:10.5270/OceanObs09.cwp.55.

26. Heimbach, P. \& Co-Authors (2010). "Observational Requirements for Global-Scale Ocean Climate Analysis: Lessons from Ocean State Estimation" in these proceedings (Vol. 2), doi:10.5270/OceanObs09.cwp.42.

27. Baehr, J. (2009). Influence of the $26^{\circ} \mathrm{N}$ RAPID/MOCHA array and Florida Current cable observations on the ECCOGODAE state estimate. $J$. Phys. Oceanog., doi:10.1175/2009JPO4118.1.

28. Smith, G. C., K. Haines, T. Kanzow, and S. A. Cunningham, 2009: Impact of hydrographic data assimilation on the Atlantic meridional overturning circulation. Ocean Science, Ocean Sci. Discuss., 6, 2667-2715, www.ocean-sci-discuss.net/6/2667/2009/.

29. Cunningham, S. \& Co-Authors (2010). "The Present and Future System for Measuring the Atlantic Meridional Overturning Circulation and Heat Transport" in these proceedings (Vol. 2), doi:10.5270/OceanObs09.cwp.21.

30. Cunningham S. A., T. Kanzow, D. Rayner, M. O. Baringer, W. E. Johns, J. Marotzke, H. R. Longworth, E. M. Grant, J. J.-M. Hirschi, L. M. Beal, C. S. Meinen, H. L. Bryden, (2007). Temporal Variability of the Atlantic Meridional Overturning Circulation at $26.5^{\circ}$ N. Science, Vol. 317. no. 5840, pp. 935 - 938 , Doi:10.1126/science.1141304.

31. Kanzow, T., et al. (2007). Flow compensation associated with the $\mathrm{OC}$ at $26.5^{\circ} \mathrm{N}$ in the Atlantic. Science, 2007. 317(17 August 2007): p. 938-941.

32. Bryden, H.L., H.R. Longworth, and S.A. Cunningham (2005). Slowing of the Atlantic Meridional Overturning Circulation at $26.5^{\circ} \mathrm{N}$. Nature, 438(10.1038): p. 655-657. 
33. Wunsch, C. and P. Heimbach, 2006: Estimated Decadal Changes in the North Atlantic Meridional Overturning and Heat Flux 1993-2004. J. Phys. Oceanogr., 36(11), 2012Đ2024, doi:10.1175/JPO2957.1

34. Bryden, H. L., A. Mujahid, S. A. Cunningham, and T. Kanzow (2009). Adjustment of the basin-scale circulation at $26^{\circ} \mathrm{N}$ to variations in Gulf Stream, deep western boundary current and Ekman transports as observed by the Rapid array. Ocean Sci., 5, 421433.

35. Hirschi, J., et al., (2003). A monitoring design for the Atlantic meridional overturning circulation. Geophys. Res. Letters, 2003. 30(7): 1413. doi:10.1029/2002GL016776.

36. Baehr, J., et al., (2004). Monitoring the meridional overturning circulation in the North Atlantic: a model-based array design study. J. Mar. Res. 62(3): p. 283-312.

37. Send, U. \& Co-Authors (2010). "A Global Boundary Current Circulation Observing Network" in these proceedings (Vol. 2), doi:10.5270/OceanObs09.cwp.78.

38. Send, U., et al., (2002). Monitoring the Atlantic meridional overturning circulation at $16 \mathrm{~N}$, in CLIVAR Exchanges. 2002. p. 1-4.

39. Keenlyside, N.S., et al., (2008). Advancing decadalscale climate prediction in the North Atlantic sector. Nature, 453(doi:10.1038/nature06921): p. 84-88.

40. Schott, F. A., Fisher, J., Dengler, M. \& Zantopp, R. Variability of the Deep Western Boundary Current east of the Grand Banks. Geophys. Res. Lett. 33, L21S07, doi:10.1029/2006GL026563 (2006).

41. Bryden, H. L., Johns, W. E. \& Saunders, P. M. Deep western boundary current east of Abaco: Mean structure and transport. J. Mar. Res. 63, 35-57 (2005).

42. Stommel and Arons, 1960. Stommel, H. \& Arons, A. B. On the abyssal circulation of the World Ocean - I. Stationary planetary flow patterns on a sphere. DeepSea Res. 6, 140-154 (1960).

43. Palmer, M. D., H. L. Bryden, J. Hirschi and J. Marotzke. 2004. Observed changes in the South Indian Ocean gyre circulation, 1987-2002, Geophysical Research Letters, 31, L15303, doi:10.1029/2004GL020506.

44. Sloyan, B.M. and S.R. Rintoul, 2001. The Southern Ocean limb of the global deep overturning circulation. J. Phys. Oceanog., 31(1): p. 143-173.

45. Whitworth, Argentine Basin Whitworth III, T., Nowlin, W. D., Pillsbury, R. D., Moore, M. I. \& Weiss, R. F. (1991). Observations of the Antarctic Circumpolar Current and deep boundary current in the Southwest Atlantic. J. Geophys. Res. 96, 15105-15118.

46. Hogg, NG; Siedler, G; Zenk, W, 1999. Circulation and variability at the southern boundary of the Brazil Basin. J. Phys. Oceanog., 29, 145-157.
47. Hall, MM; McCartney, M; Whitehead, JA, 1997. Antarctic Bottom Water flux in the equatorial western Atlantic. J. Phys. Oceanog., 27, 1903-1926.

48. Warren, BA; Whitworth, T; LaCasce, JH , 2002. Forced resonant undulation in the deep Mascarene Basin. Deep-Sea Res. II, 7-8, 1513-1526.

49. Sloyan, B. M., (2006), Antarctic bottom and lower circumpolar deep water circulation in the eastern Indian Ocean, J. Geophys. Res., 111, C02006, doi:10.1029/2005JC003011.

50. Whitworth, T. III, B. A. Warren, W. D. Nowlin Jr., S. B. Rutz, R. D. Pillsbury, and M. I. Moore. (1999). On the deep western-boundary current in the Southwest Pacific Basin. Progress in Oceanography, 43, 1-54.

51. Rudnick, DL, 1997. Direct velocity measurements in the Samoan passage. J. Geophys. Res. - Oceans, 102, 3293-3302.

52. Kawabe, M; Yanagimoto, D; Kitagawa, S., 2006.Variations of deep western boundary currents in the Melanesian Basin in the western North Pacific. Deep-Sea Res. I, 53, 942-959.

53. Fukamachi, Y., S. Aoki, J. A. Church, S. R. Rintoul, M Rosenberg, and M. Wakatsuchi, (2009). Mooring measurements of the deep western boundary current over the eastern flank of the Kerguelen Plateau, Nature Geoscience, doi:10.1038/NGEO842.

54. Böning, C. W., A. Dispert, M. Visbeck, S. R. Rintoul, and F. Schwarzkopf, 2008. Response of the Antarctic Circumpolar Current to recent climate change. Nature Geoscience, doi:10.1038/ngeo362.

55. Key, R. M., A. Kozyr, C. L. Sabine, K. Lee, R. Wanninkhof, J. L. Bullister, R. A. Feely, F. J. Millero, C. Mordy, and T. H. Peng (2004), A global ocean carbon climatology: Results from Global Data Analysis Project (GLODAP), Global Biogeochemical Cycles, 18, GB4031, doi:10.1029/2004GB002247.

56. Wanninkhof, R., S. C. Doney, R. D. Castle, F. J. Millero, J. L. Bullister, D. A. Hansell, M. J. Warner, C. Langdon, G. C. Johnson, and C. W. Mordy (2006), Carbon dioxide, hydrographic and chemical data obtained during the $R / V$ Ronald $H$. Borwn repeat hydrography cruise in the Atantic Ocean: CLIVAR $\mathrm{CO}_{2}$ section A16S_2005, edited by A. Kozyr, p. 28, RNL/CDIAC-151NDP-087.

57. Garzoli, S. \& Co-Authors (2010). "Progressing Towards Global Sustained Deep Ocean Observations" in these proceedings (Vol. 2), doi:10.5270/OceanObs09.cwp.34.

58. Murata, A., Y. Kumamoto, K. Sasaki, S. Watanabe, and M. Fukasawa, (2008). Decadal increases of anthropogenic $\mathrm{CO}_{2}$ in the subtropical South Atlantic Ocean along 30S, J. of Geophys. Res., C06007, doi:10.1029/2007JC004424

59. Murata, A., Y. Kumamoto, S. Watanabe, and M. Fukasawa, (2006). Decadal increases of anthropogenic $\mathrm{CO}_{2}$ in the South Pacific subtropical 
ocean along $32^{\circ} \mathrm{S}$, Journal of Geophysical Research, 112, C05033, doi:10.1029/2005JC003405.

60. Lo Monaco C, Goyet C, Metzl N, Poisson A, Touratier F.2005b. Distribution and inventory of anthropogenic $\mathrm{CO}_{2}$ in the Southern Ocean: Comparison of three data-based methods. J. Geophys. Res. 110:C09S02

61. Wallace, W. R., (2001). Storage and transport of excess $\mathrm{CO}_{2}$ in the oceans: the JGOFS/WOCE global CO2 survey, in Ocean circulation and climate, edited by G. Siedler, pp. 489-521, Academic Press, AIP International Geophysics Series.

62. Latif, M., et al., (2006). A review of predictability studies of Atlantic sector climate on decadal time scales. J. Clim., 2006. 19: p. 5971-5987.

63. Zhang, R., and T. L. Delworth (2006), Impact of Atlantic multidecadal oscillations on India/Sahel rainfall and Atlantic hurricanes, Geophys. Res. Lett., 33, L17712, doi:10.1029/2006GL026267.

64. Latif, M., 1998: Dynamics of interdecadal variability in coupled ocean-atmosphere models. J. Climate, 11, 602-624.

65. Bjerknes, J., 1964: Atlantic air-sea interaction. Advances in Geophysics, Academic Press, 10, 1-82.

66. Balmaseda, M. \& Co-Authors (2010). "Initialization for Seasonal and Decadal Forecasts" in these proceedings (Vol. 2), doi:10.5270/OceanObs09.cwp.02.

67. Smith, D. M., S. Cusack, A. W. Colman, C. K. Folland, G. R. Harris and J. M. Murphy, 2007: Improved Surface Temperature Prediction for the Coming Decade from a Global Climate Model, Science, 317, 796-799.

68. Palmer, M. \& Co-Authors (2010). "Future Observations for Monitoring Global Ocean Heat Content" in these proceedings (Vol. 2), doi:10.5270/OceanObs09.cwp.68.

69. Hood, M. \& Co-Authors (2010). "Ship-Based Repeat Hydrography: A Strategy for a Sustained Global Program." in these proceedings (Vol. 2), doi:10.5270/OceanObs09.cwp.44.

70. Johnson, G. C. and S. C. Doney, 2006: Recent western South Atlantic bottom water warming. Geophys. Res. Lett., 33, L14614, doi:10.1029/2006GL026769.

71. Johnson, G. C., S. G. Purkey, and J. L. Bullister, (2008). Warming and freshening in the abyssal southeastern Indian Ocean. J. Climate, 21, 53515363, doi:10.1175/2008JCLI2384.1.

72. Johnson, G. C., S. Mecking, B. M. Sloyan, and S. E. Wijffels, 2007: Recent bottom water warming in the Pacific Ocean. J. Climate, 20, 5365-5375, doi:10.1175/2007JCLI1879.1.

73. Fukasawa, M., H. Freeland, R. Perkin, T. Watanabe, H. Uchida and A. Nishina, (2004). Bottom water warming in the North Pacific Ocean. Nature 427, 825-827.
74. Fahrbach, E., M. Hoppema, G. Rohardt, M. Schröder and A. Wisotzki, (2004). Decadal-scale variations of water mass properties in the deep Weddell Sea. Ocean Dynamics, 54, 77-31.

75. Kawano, T., et al., (2006). Bottom water warming along the pathway of Lower Circumpolar Deep Water in the Pacific Ocean. Geophys. Res. Letters, 33(L23613): p. doi:10.1029/2006GL027933.

76. Levitus, S., J. Antonov, and T. Boyer, (2005). Warming of the world ocean, 1955 - 2003. Geophys. Res. Lett., VOL. 32, L02604, doi:10.1029/2004GL021592.

77. Domingues, C. M., J. A. Church, N. J. White, P. J. Gleckler, S. E. Wijffels, P. M. Barker, J. R. Dunn, (2008). Rapid upper-ocean warming helps explain multi-decadal sea-level rise, Nature, 453:1090-1093.

78. Bindoff, N., J. Willebrand, V. Artale, A. Cazenave, J. Gregory, S. Gulev, K. Hanawa, C. Le Quere, S. Levitus, Y. Nojiri, C. K. Shum, L. Talley and A. Unnikrishnan, (2007). Observations: oceanic climate change and sea level. Climate Change 2007: The Physical Science Basis. Contribution of Working Group I to the Fourth Assessment Report of the Intergovernmental Panel on Climate Change, $\mathrm{S}$. Solomon, D. Qin, M. Manning, Z. Chen, M. Marquis, K.B. Averyt, M. Tignor and H. L.Miller, Eds., Cambridge University Press, Cambridge, 385-432.79.

79. Levitus,. J. I. Antonov, J. Wang, T. L. Delworth, K. W. Dixon, A. J. Broccoli, (2001). Anthropogenic Warming of Earth's Climate System. Science, 292, $267-270$

80. Hansen, J., L. Nazarenko, R. Ruedy, M. Sato, J. Willis, A. Del Genio, D. Koch, A. Lacis, K. Lo, S. Menon, T. Novakov, J. Perlwitz, G. Russell, G. A. Schmidt, and N. Tausnev, (2005). Earth's energy imbalance: Confirmation and implications. Science, 308, 1431 1435

81. Durack, P.J and S.E. Wijffels, 2010. Fifty-Year Trends in Global Ocean Salinities and their relationship to Broad-Scale Warming. Journal of Climate (accepted).

82. Roemmich, D. and J. Gilson (2009) The 2004-2008 mean and annual cycle of temperature, salinity, and steric height in the global ocean from the Argo Program. Progress in Oceanography, 82, 81-100 doi:10.1016/j.pocean.2009.03.004.

83. Hosoda, S., T. Sugo, N. Shikama and K. Mizuno (2009) Global Surface Layer Salinity Change Detected by Argo and Its Implication for Hydrological Cycle Intensification. Journal of Oceanography, 65, pp 579-586.

84. Dickson, B., I. Yashayaev, J. Meincke, B. Turrell, S. Dye and J. Holfort, (2002). Rapid freshening of the deep North Atlantic Ocean over the past four decades. Nature, 416, 832-837.

85. Hátún, H., A. B. Sandø and H. Drange, (2005) Influence of the Atlantic Subpolar Gyre on the thermohaline circulation. Science, 309: 1841-1844. 
86. Häkkinen, S., and P. B. Rhines, (2004). Decline of subpolar North Atlantic circulation during the 1990s. Science, 304: 555-559.

87. Bersch, M., I. Yashayaev, and K. P. Koltermann, (2007). Recent changes of the thermohaline circulation in the subpolar North Atlantic. Ocean Dynamics, 57: 223-235.

88. Holliday, N.P., S. L. Hughes, S. Bacon, A. Beszczynska-Moeller, B. Hansen, A. Lavin, H. Loeng, K. A. Mork, S. Østerhus, T. Sherwin, W. Walczowski, (2008). Reversal of the 1960s to 1990s freshening trend in the northeast North Atlantic and Nordic Seas. Geophys. Res. Lett., 35, L03614, doi:10.1029/2007GL032675.

89. Sarafanov, A., Falina, A., Sokov, A., and Demidov, A., (2008). Intense warming and salinification of intermediate waters of southern origin in the eastern subpolar North Atlantic in the 1990s to mid-2000s. Journal of Geophysical Research, 113, C12022, doi:10.1029/2008JC004975.

90. Hakkinen, S; Rhines, PB, 2009. Shifting surface currents in the northern North Atlantic Ocean. $J$. Geophys. Res. - Oceans, 114, C04005.

91. Sarafanov, A., Sokov, A., Demidov, A., and Falina, A., (2007). Warming and salinification of intermediate and deep waters in the Irminger Sea and Iceland Basin in 1997-2006. Geophysical Research Letters, 34, L23609, doi:10.1029/2007GL031074.

92. Yashayaev, I., (2007). Hydrographic changes in the Labrador Sea, 1960-2005. Progress in Oceanography, 73: 242-276.

93. Sarafanov, A., (2009). On the effect of the North Atlantic Oscillation on temperature and salinity of the subpolar North Atlantic intermediate and deep waters, ICES Journal of Marine Science, 66, 14481454

94. Whitworth, T., III., (2002). Two modes of bottom water in the Australian-Antarctic Basin, Geophys. Res. Lett., 29(5), 1073, doi:10.1029/2001GL014282.

95. Jacobs, S.S. (2004). Bottom water production and its links with the thermohaline circulation. Antarctic Science 16 (4): 427-437.

96. Jacobs, S. S. (2006). Observations of change in the Southern Ocean. Phil. Trans. Roy. Soc. A, 364, $1657-$ 1681, doi:10.1098/rsta.2006.1794.

97. Aoki, S and N. F. Bindoff, and J. A. Church, (2005a). Interdecadal water mass changes in the Southern Ocean between 30E and 160E. Geophys. Res. Lett., 32 (L07607). pp. 1-5. ISSN 0094-8276.

98. Aoki, S., S. R. Rintoul, S. Ushio, S. Watanabe, and N. L. Bindoff, (2005b). Freshening of the Adelie Land Bottom Water near $140^{\circ} \mathrm{E}$, Geophys. Res. Lett., Vol. 32, L23601, doi:10.1029/2005GL024246.

99. Rintoul., S. R., (2007). Rapid freshening of Antarctic Bottom Water formed in the Indian and Pacific
Oceans. Geophys. Res. Lett., 34, L06606, doi:10.1029/2006GL028550.

100. Jacobs, S. S., C. F. Guilivi and P. Merle, (2002). Freshening of the Ross Sea during the late 20th century. Science, 297, 386-389.

101. Rignot, E., and S. S. Jacobs (2002), Rapid bottom melting widespread near Antarctic ice sheet grounding lines, Science, 296, 2020-2023.

102. Shepherd, A., D. Wingham and E. Rignot, (2004). Warm ocean is eroding West Antarctic ice sheet. Geophys. Res. Lett. 31, L23402, doi:10.1029/2004GL021106.

103. Heywood, K. J., A. F. Thompson, E. Fahrbach, A. Mackensen, and S. Aoki, (2009). Cooling and Freshening of the Weddell Sea Outflow. Geophys. Res. Abstracts, Vol. 11, EGU2009-4336. EGU General Assembly 2009.

104. Meinen and Watts, 2000: Vertical structure and transport on a transect across the North Atlantic Current near 428N. J. Geophys. Res., 105, 21 869-21 891.

105. Shum, C. \& Co-Authors (2010). "Geodetic Observations of the Ocean Surface Topography, Geoid, Currents, and Changes in Ocean Mass and Volume" in these proceedings (Vol. 2), doi:10.5270/OceanObs09.cwp.80.

106. Send, U. \& Co-Authors (2010). "OceanSITES" in these proceedings (Vol. 2), doi:10.5270/OceanObs09.cwp.79.

107. Dushaw, B. \& Co-Authors (2010). "A Global Ocean Acoustic Observing Network" in these proceedings (Vol. 2), doi:10.5270/OceanObs09.cwp.25.

108. Kieke, D., et al., Changes in the pool of Labrador Sea Water in the subpolar North Atlantic. Geophys. Res. Letters, 2007. 34(L06605): p. doi:10.1029/2006GL028959.

109. Bingham, R.J., et al., (2007). Meridional coherence of the North Atlantic meridional overturning circulation. Geophys. Res. Letters, 34(L23606): p. doi:10.1029/2007GL031731.

110. Biastoch, A., et al., (2008). Causes of interannualdecadal variability in the meridional overturning circulation of the midlatitude North Atlantic Ocean. J. Clim. 21(24): p. 6599-6615.

111. Baehr, J., A. Stroup, and J. Marotzke, 2009. Testing concepts for continuous monitoring of the meridional overturning circulation in the South Atlantic. Ocean Modelling, 9, 147-153.

112. Bacon, S. and P.M. Saunders, (2009). The Deep Western Boundary Current at Cape Farewell: Results from a moored current meter array. J. Phys. Oceanog., accepted.

113. Weijer, W., et al., (1999). Impact of interbasin exchange on the Atlantic overturning circulation. $J$ Phys. Oceanog., 29, 2266-2284. 
114. Caltabiano, A., (2007). A monitoring system for heat and mass transports in the South Atlantic as a component of the Meridional Overturning Circulation, Estancia San Ceferino, Buenos Aires, Argentina, May 8, 9, and 10, 2007, in Workshop Report. 2007, International CLIVAR Project Office: Southampton. p. 38.

115. Rintoul, S. \& Co-Authors (2010). "Southern Ocean Observing System (SOOS): Rationale and Strategy for Sustained Observations of the Southern Ocean" in these proceedings (Vol. 2),

doi:10.5270/OceanObs09.cwp.74. 